\title{
Degree of Deacetylation of Chitosan Extracted from White Snapper (Lates sp.) Scales Waste
}

\author{
Noverita D. Takarina, Aldila A. Nasrul, and Alinda Nurmarina \\ Department of Biology, Universitas Indonesia, Depok, Indonesia \\ Email: noverita.dian@sci.ui.ac.id, \{aamininasrul, alindamarina96\}@ gmail.com
}

\begin{abstract}
Chitosan is natural biopolymer which can be obtained from natural resources even from wastes such fish scales. Indonesia is one of countries that having high fish production. White snapper (Lates sp.) is seawater fish that has an economical value since it is preferred by many consumers. New challenge to this condition is how to manage the waste from fish processing into useable materials. This study was aimed to extract chitosan from white snapper (Lates sp.) scales and to determine the degree of deacetylation of the chitosan based on the treatment differences in temperature, heating duration, and the $\mathrm{NaOH}$ concentration. Chitosan from white snapper scales were extracted through three stages, deprotenization, demineralization and deacetylation. Different treatment on deacetylation stages based on variation of $\mathrm{NaOH}$ concentration, temperature and duration of heating. Degree of deacetylation were measured using FTIR spectrophotometry based on infrared light absorbance. Result showed that chitosan produced were fulfilled minimum requirement for good quality of chitosan. Highest deacetylation degree was $84.05 \%$, resulted from treatment number 15 with $\mathrm{NaOH}$ concentration of $80 \%$, temperature of $120^{\circ} \mathrm{C}$ and duration of heating for 4 hours.
\end{abstract}

Index Terms - chitosan, degree of deacetylation, fish scale, white snapper, FTIR

\section{INTRODUCTION}

Chitosan is a natural product which is a derivative of the polysaccharide chitin. Chitosan has the chemical name Poly D-glucosamine (beta (1-4) 2-amino-2-deoxyD-glucose. Chitosan can be used in various fields of biochemistry, medical or pharmaceutical, food and nutrition, agriculture, microbiology, paper industries, textile membrane or film, cosmetics, and wastewater treatment.

Waste from seafood processing for example crustaceans shell are abundantly found and are the most common source of chitosan[1]. Chitosan also can be isolated from freshwater fishes such as carp (Cyprinus carpio L.) scales. In addition, Uawonggul et al. (2002) [2] and Weeraphan (2011) [3], also managed to extract chitin and chitosan from fish scales of tilapia (Tilapia nilotica). Kumaria \& Rath (2014) [4] stated that chitin and chitosan can be extracted from fish scales of Labeo rohita, too. There are other potential uses of fish scales according to Ikoma et al. (2003) [5], which is as an inorganic

Manuscript received November 30, 2016; revised January 23, 2017. absorbent materials. Other than that, scales can also be used not only in separation technology but also in catalysis and biomedical applications.

Further research is needed to determine the method and characteristic of chitosan extracted from seawater fish scales, for example white snapper. Local name of white snapper is Barramundi. Barramundi (Lates sp) has a body covered with scales. The scales derived from the skin layer called the dermis.

Degree of deacetylation is a quality parameter that indicates an acetyl group which can be removed from the chitosan. The higher the degree of deacetylation of chitosan, the lower the acetyl group contained in the chitosan (Knoor, 1983) [6]. Degree of deacetylation is also determined as a percentage that indicates an acetyl missing or replaced with amines. Analysis FourierTransform Infra-Red (FTIR) is used to determine the functional groups present in chitosan. In addition, this method can be used also to determine the degree of deacetylation. The working principle of FTIR is infrared radiation will pass through the sample and then the radiation will be absorbed. The ones that are not absorbed will be forwarded passing the transmittances resulting in a spectrum of absorption in the infrared region therefore cause the vibration of the bond in the molecules. This study was aimed to extract chitosan from white snapper fish (Lates sp.) scales and to determine the degree of deacetylation of the chitosan based on the treatment differences in temperature, heating duration, and the $\mathrm{NaOH}$ concentration.

\section{Methodology}

\section{A. Preparation of Fish Scale}

$15 \mathrm{~kg}$ of fish scales were collected from Bening Food Companies at Parung, Bogor. Fish scales then washed using running water to remove dirt and other odd particles. After that, samples were air-dried. Dry fish scales ware stored in room temperature before the extraction process started.

\section{B. Extraction of Chitosan from Fish Scale}

Chitosan were extracted based on [3]. The extraction consists of three stages, deproteinization, demineralization, and deacetylation. Deproteinization was done using a solution of $4.2 \% \mathrm{NaOH}$ and the ratio between the fish scales with a solution of $\mathrm{NaOH}$ was 1: 6 . 
The process of making $4.2 \% \mathrm{NaOH}$ solution was by dissolving 504 grams solid $\mathrm{NaOH}$ using distilled water up to $1000 \mathrm{ml}$ volume in the beaker glass. The solution then was added by $11 \mathrm{~L}$ of distilled water. $2 \mathrm{~kg}$ of fish scales were added to $2 \mathrm{~L}$ of $4.2 \% \mathrm{NaOH}$ solution, mixed, then heated using hotplate with a constant temperature of $60{ }^{\circ} \mathrm{C}$, and stirred using spatula periodically for 6 hours. Deproteinization residue was filtered and neutralized using distilled water. The residue that has reached a $\mathrm{pH}$ of 7 was dried using an oven with a temperature of $60{ }^{\circ} \mathrm{C}$ for 12 hours. The dried residue was then prepared for demineralization process.

Demineralization was carried out using $2 \mathrm{~N} 4.2 \% \mathrm{HCl}$ solution and the ratio between deproteinization residue with a solution of $\mathrm{HCl}$ was 1: 6 . Demineralization began by adding the $4.2 \% \mathrm{HCl}$ solution in a pyrex glass containing deproteinization residue. The solution is then stirred periodically in room temperature for 5 hours. Demineralization residue then filtered and neutralized using distilled water until its $\mathrm{pH}$ reached 7 . The residue was dried using an oven with a temperature of $60{ }^{\circ} \mathrm{C}$ for 12 hours. Final product of demineralization is chitin.

Samples resulted from demineralization process were tested using complete random design with variation on $\mathrm{NaOH}$ concentration, temperature, and duration of heating.

Table I showed parameters used which were: $\mathrm{NaOH}$ concentrations $(60 \%, 70 \%, 80 \%)$, temperature (110, $120,130^{\circ} \mathrm{C}$ ) and duration of heating (4, 6 hours). The steps of deacetylation of white snapper fish scales divided into 18 treatments (number 1-18).

\section{Measurement of Degree of Deacetylation on Chitosan}

Degree of deacetylation was characterized using FTIR spectrophotometry with computation by providing infrared light on a sample of chitosan and then the infrared absorbance was recorded. Hydroxyl groups calculated at a wavelength of $3450 \mathrm{~cm}^{-1}$, whereas the amide group is at a wavelength of $1655 \mathrm{~cm}^{-1}$. Deacetylation degree of chitosan can be calculated using this following equation as in (1) [7]:

$$
\% \mathrm{DD}=100-\left[\frac{\mathrm{A}_{1655}}{\mathrm{~A}_{3450}} \times \frac{100}{1,33}\right]
$$

Chitosan $\mathrm{A}_{1655}=$ absorbance at a wavelength of $1655 \mathrm{~cm}^{-1}$ Chitosan $A_{3450}=$ absorbance at a wavelength of $3450 \mathrm{~cm}^{-1}$

TABLE I. DEACETYLATION TREATMENT

\begin{tabular}{cccc}
\hline \multicolumn{3}{c}{ Parameter } \\
\hline $\begin{array}{c}\text { Treatment } \\
\text { number }\end{array}$ & $\begin{array}{c}\text { NaOH } \\
(\boldsymbol{\%})\end{array}$ & $\begin{array}{c}\text { Temperature } \\
\left({ }^{\circ} \mathbf{C}\right)\end{array}$ & $\begin{array}{c}\text { Time } \\
\text { (hours) }\end{array}$ \\
\hline $\mathbf{1}$ & 60 & 110 & 4 \\
\hline $\mathbf{2}$ & 60 & 110 & 6 \\
\hline $\mathbf{3}$ & 60 & 120 & 4 \\
\hline $\mathbf{4}$ & 60 & 120 & 6 \\
\hline $\mathbf{5}$ & 60 & 130 & 4 \\
\hline $\mathbf{6}$ & 60 & 130 & 6 \\
\hline $\mathbf{7}$ & 70 & 110 & 4 \\
\hline $\mathbf{8}$ & 70 & 110 & 6 \\
\hline $\mathbf{9}$ & 70 & 120 & 4 \\
\hline $\mathbf{1 0}$ & 70 & 120 & 6 \\
\hline $\mathbf{1 1}$ & 70 & 130 & 4 \\
\hline $\mathbf{1 2}$ & 70 & 130 & 6 \\
\hline $\mathbf{1 3}$ & 80 & 110 & 4 \\
\hline $\mathbf{1 4}$ & 80 & 110 & 6 \\
\hline $\mathbf{1 5}$ & 80 & 120 & 4 \\
\hline $\mathbf{1 6}$ & 80 & 120 & 6 \\
\hline $\mathbf{1 7}$ & 80 & 130 & 4 \\
\hline $\mathbf{1 8}$ & 80 & 130 & 6 \\
\hline
\end{tabular}

\section{RESULT AND DISCUSSION}

Chitosan is produced through three processes, which are deproteinization, demineralization and deacetylation. Deproteinization is protein removal process using alkaline solution, to produce deproteinization residue. Meanwhile, the demineralization process is removal of the metal content of deproteinization residue, generating residual demineralized form of chitin. Chitosan is produced from chitin by a deacetylation process. Deacetylation is the removal of acetyl groups (-COCH3) on chitin and turn it into an amine group (NH2) using an alkaline solution. Degree of deacetylation on chitosan extracted from white snapper fish scales is showed at Table II.

TABLE II. DEGREE OF DEACETylation ON ChITOSAN EXTRACTED FROM White SNAPPER Fish SCALE

\begin{tabular}{|c|c|c|c|c|c|c|c|c|c|c|c|c|c|c|c|c|c|c|}
\hline $\begin{array}{c}\text { Treatment } \\
\text { number }\end{array}$ & 1 & 2 & 3 & 4 & 5 & 6 & 7 & 8 & 9 & 10 & 11 & 12 & 13 & 14 & 15 & 16 & 17 & 18 \\
\hline DD (\%) & 78,35 & 80,51 & 77,09 & 79,25 & 81,72 & 82,02 & 80,19 & 80,59 & 82,30 & 81,45 & 75,00 & 79,79 & 77,49 & 79,22 & 84,05 & 76,09 & 77,41 & 75,58 \\
\hline
\end{tabular}

Formation of chitosan from chitin occurs through an amide hydrolysis reaction using a base. Chitin plays role as an amides and $\mathrm{NaOH}$ as a base. The process begins with an additional reaction, namely the inclusion of the $\mathrm{OH}$ group into the group $\mathrm{NHCOCH} 3$. Then chitosan produced through the elimination of cluster $\mathrm{CH} 3 \mathrm{COO}$ [8]. The degree of deacetylation of the chitosan obtained from white snapper fish scales ranged from $75.00 \%$ to $84.05 \%$. Degree of deacetylation was calculated based on FTIR using equation Dosmzy \& Robert (1984). The highest degree of deacetylation was $84.05 \%$ which was obtained from treatment number $15(\mathrm{NaOH}$ concentration of $80 \%$, temperature of $120^{\circ} \mathrm{C}$, duration of heating for 4 hours), while the treatment number $11 \quad(\mathrm{NaOH}$ concentration of $70 \%$, temperature of $130^{\circ} \mathrm{C}$, duration of heating for 4 hours) showed lowest degree of deacetylation which was $75.00 \%$. The quality standard of chitosan according to SNI 7949: 2013 is when the degree of deacetylation of chitosan reaches a minimum value of $75 \%$. It showed that chitosan resulted from white snapper fish scales fulfilled the standard. 
Fig. 1 showed the FTIR graph which performed chitosan with higher degree of deacetylation by calculating the distance between two absorbance values
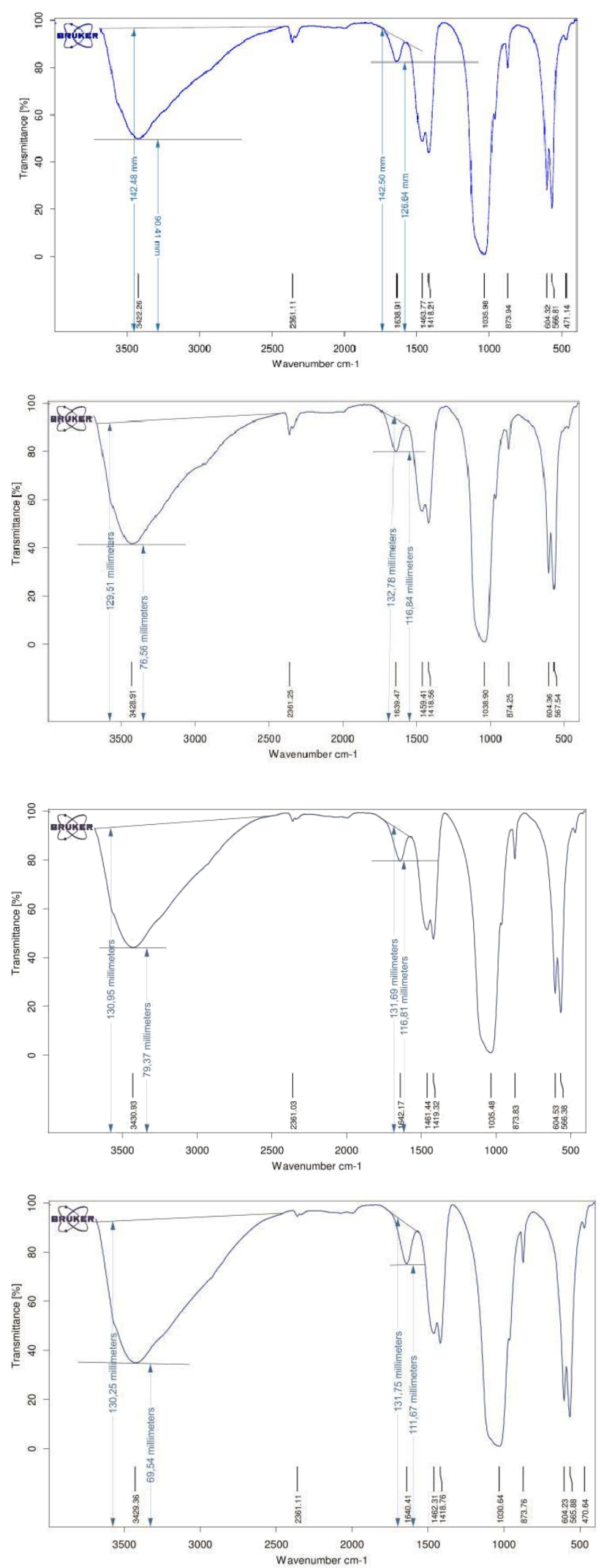

which were 1655 and 3450 wavelength. The distances then were measured based on there the highest and lowest point.
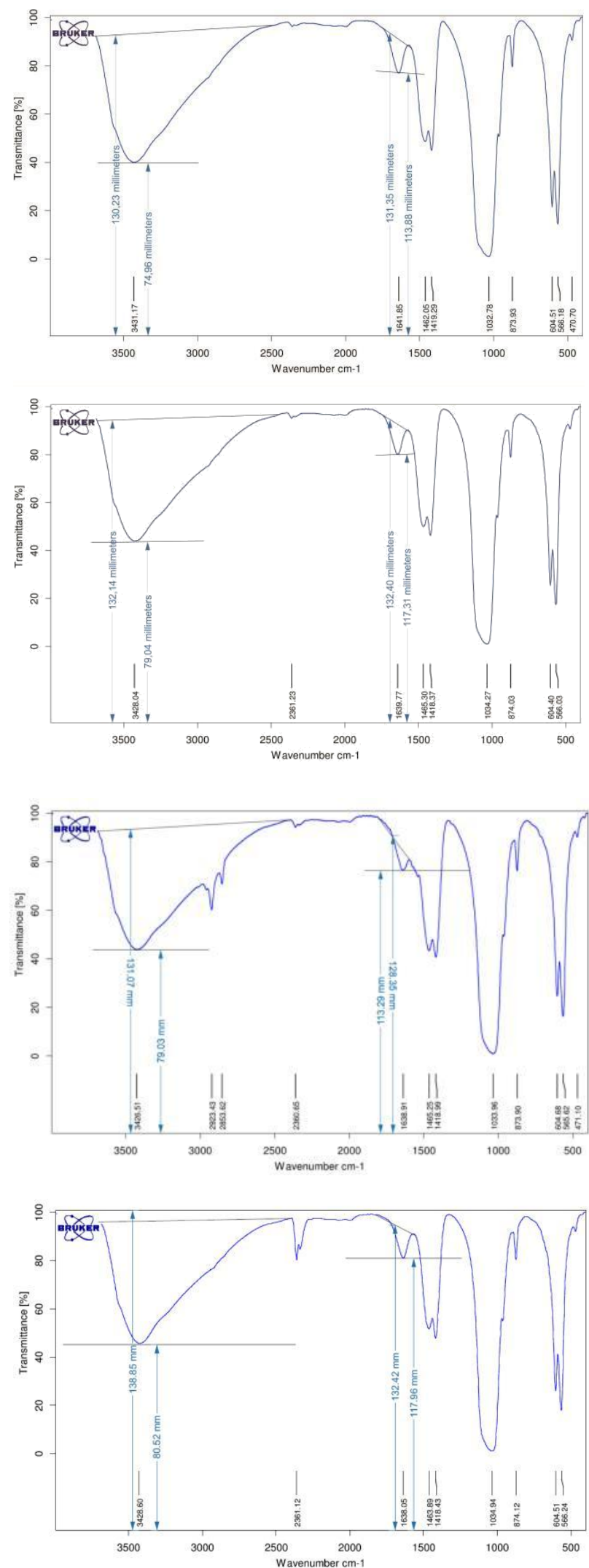

Figure 1. FTIR graph of treatment showing chitosan with DD higher than $80 \%$ (Treatment 2, 5, 6, 7, 8, 9, 10, 15) 
The amount of percent degree of deacetylation can be used to determine the quality of chitosan. Base line method proposed by [7] used to calculate the percentage of the degree of deacetylation of the chitosan scales white snapper. Chitosan is said to have been deacetylated perfectly if DD> 90\% [9].

\section{CONCLUSION}

Deacetylation degree of $84,05 \%$ was resulted from treatment number 15 with temperature of $120{ }^{\circ} \mathrm{C}, \mathrm{NaOH}$ concentration of $80 \%$, and duration of heating for 4 hours.

\section{ACKNOWLEDGMENT}

We acknowledge Ministry of Higher Education, Research, and Technology and Directorate of Research and Community Engagement, Universitas Indonesia through PITTA UI grants Fiscal Year 2016 with contract number 2047/UN2.R12/HKP.05.00/2016.

\section{REFERENCES}

[1] S. G. Zaku, S. A. Emmanuel, O. C. Aguzue, and S. A. Thomas, "Extraction and characterization of chitin, a functional biopolymer obtained from scales of common carp fish (Cyprinus carpio L.): A lesser known source," African Journal of Food Science, vol. 5, no. 8, pp. 478-483, 2011.

[2] N. Uawonggul, S. Kongsri, and S. Chantai, "Study on dyebinding interactions of chitosan obtained from fish scale of tilapia (Tilapia nilotica)," International Journal of Pure and Applied Chemistry, vol. 6, no. 2, pp. 129-147, 2011.

[3] W. Weeraphan, "Chitosan extraction from fish scale of tilapia (Tilapia nilotica) for edible film production," thesis, Chiang Mai University, Thailand, 2011.

[4] S. Kumaria and P. K. Rathb, "Extraction and characterization of chitin and chitosan from (Labeo rohit) fish scales," Procedia Materials Science, vol. 6, pp. 482 - 489, 2014.

[5] T. Ikoma, K. Hisatoshi, T. Junzo, W. Dominic, and M. Stephen, "Microstructure, mechanical and biomimetic properties of fish scales from pagrus major," Journal of Structural Biology, vol. 142, pp. 327-333, 2003.

[6] D. Knorr, "Dye binding properties of chitin and chitosan," Journal of Food Science, vol. 48, pp. 36-37, 1983.

[7] J. G. Domszy and G. A. F. Robert, "Evaluation of infrared spectroscopic technique for analyzing chitosan," Journal of Macromoleculer: Science- Pure Applied Chemistry, vol. 8, pp. 1671-1677, 1984.

[8] F. W. Mahatmanti, "Study adsorben logam seng (II) dan timbal (II) pada kitosan dan kitosan sulfat dari kulit udang windu (Penaus monodon)," thesis, UGM, Yogyakarta, 2001.
[9] B. Srijanto, "Kajian pengembangan teknologi proses produksi kitin dan kitosan secara kimiawi," in Proc. Seminar Nasional Teknik Kimia Indonesia, 2003, vol. 1, pp. F01-1 -F01-5.

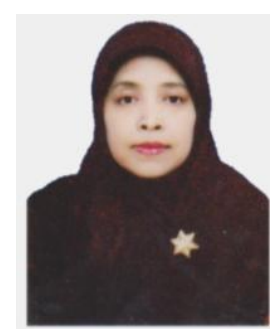

Dr. Noverita Dian Takarina, M.Sc was born in Surakarta, Central of Java on $16^{\text {th }}$ November 1965. She received Bachelor degree in 1990 at Faculty of Biology, Universitas Gadjah Mada, and she received her M.Sc degree in 1996 at McMaster University, Hamilton, Ontario, Canada in cooperation with Six Universities Development and Rehabilitation-Asian Development Bank (SUDR-ADB) Scholarship. She received her Doctoral degree at Institut Pertanian Bogor (IPB) and funded by Universitas Indonesia scholarship.

She wrote four articles published by international journal in 2013 and four articles published by accredited national journal in 2010, 2011, and 2013. While undergoing Doctoral degree, she wrote international scientific paper, titled Geochemical Fractionation of Copper $(\mathrm{Cu})$, Lead $(\mathrm{Pb})$, and Zinc $(\mathrm{Zn})$ in Sedimen and their Correlations with Concentration in Bivalve Mollusc Anadara indica from Coastal Area of Banten Province, Indonesia. That paper published by International Journal of Marine Science in 2013. She also wrote national scientific paper, titled Bioconcentration Factor of Copper $(\mathrm{Cu})$, Lead $(\mathrm{Pb})$, and Zinc (Zn) in Anadara indica Related to the Water Quality in Coastal Areas published by Makara of Science Series UI Journal.

She has received an award from the Universitas Indonesia as a writer in the international journal of Marine Pollution Bulletin, published in 2004.

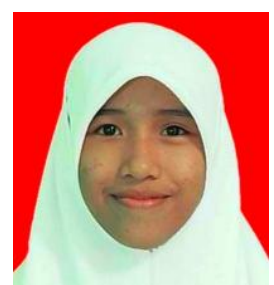

Aldila Amini Nasrul was born in Makassar, South Sulawesi at $13^{\text {th }}$ March 1996. she is studying in Department of Biology, Faculty of Mathematics and Natural Sciences, Universitas Indonesia, Depok, West Java, Indonesia.

She has been a speaker of an international seminar MSCEIS (Mathematics Science and Computer Science Education) at Universitas Pendidikan Indonesia, Bandung and speaker of national seminar Association of Indonesian Oceanology Bachelor at Surabaya.

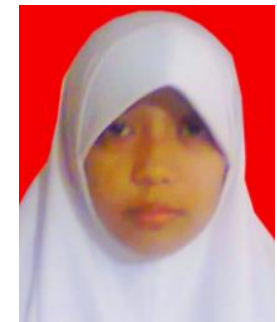

Alinda Nurmarina was born in Pandeglang, Banten at $9^{\text {th }}$ July 1996 . she is studying in Department of Biology, Faculty of Mathematics and Natural Sciences, Universitas Indonesia, Depok, West Java, Indonesia.

She has been a speaker of an international seminar MSCEIS (Mathematics Science and Computer Science Education) at Universitas Pendidikan Indonesia, Bandung and speaker of national seminar Association of Indonesian Oceanology Bachelor at Surabaya. 